\section{Population density and group size of the Grey Junglefowl Gallus sonneratii in the Melghat Tiger Reserve, Maharashtra, central India}

\author{
K. Narasimmarajan ${ }^{1}$, Bidyut B. Barman ${ }^{2}$ \& \\ Lalthan Puia ${ }^{3}$ \\ 1,2,3 Post Box No: 18, Wildlife Institute of India, Chandrabani, \\ Dehradun, Uttarakhand 248001, India \\ Email: ${ }^{1}$ wildlife9protect@gmail.com (corresponding author), \\ ${ }^{2}$ bidyutb8@gmail.com, ${ }^{3}$ lalthanpuia24@gmail.com
}

Avian community studies are effective tools for monitoring forest ecosystems. Birds are widely recognized as good bioindicators of the quality of the ecosystems and the health of the environment (Gill 1994). They are responsive to change; their diversity and abundance can reflect ecological trends in other biodiversities (Furness \& Greenwood 1993). Because of their highly specific habitat requirements, birds are increasingly intolerant of even slight ecosystem disturbances (Schwartz \& Schwartz 1951). Work on forest bird communities has been done in other parts of the country from time to time (Ramakrishnan 1983; Johnsingh et al. 1987, 1994). The Grey Junglefowl

Date of publication (online): 26 July 2012

Date of publication (print): 26 July 2012

ISSN 0974-7907 (online) | 0974-7893 (print)

Editor: Rajiv Kalsi

Manuscript details:

Ms \# 02821

Received 03 June 2011

Final received 05 June 2012

Finally accepted 29 June 2012

Citation: Narasimmarajan, K., B.B. Barman \& L. Puia (2012). Population density and group size of the Grey Junglefowl Gallus sonneratii in the Melghat Tiger Reserve, Maharashtra, central India . Journal of Threatened Taxa 4(7): 2723-2726.

Copyright: ( K. Narasimmarajan, Bidyut B. Barman \& Lalthan Puia 2012. Creative Commons Attribution 3.0 Unported License. JoTT allows unrestricted use of this article in any medium for non-profit purposes, reproduction and distribution by providing adequate credit to the authors and the source of publication.

Acknowledgements: We thank the Director and Dean, Wildlife Institute of India. We would like to thank Mr. A.K. Mishra, field director and other forest department staff in Melghat Tiger Reserve for their help for every support and accommodation. We personally thanked Dr. K. Ramesh for his valuable comments in earlier draft of the manuscript, we gratefully acknowledged the anonymous referees and special thanks to Dr. R.S. Kalsi for his positive comments during the editing. We also extend our thanks to our field assistants and driver for their dedication during the field work.

OPEN ACGESS I FREE DOWNLOAD (C) (i) Cு
(GJ), endemic to peninsular India, is listed as Least Concern in status (Birdlife International

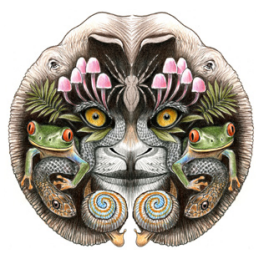
2012). Although, there have been several studies on the GJ in southern India, there are no reported studies on its population density and group size in the Melghat Tiger Reserve (Galliforms of India 2007). Hence this study was conducted as a preliminary investigation to find out the population density of the GJ in Melghat Tiger Reserve.

Study area: Melghat Tiger Reserve established in 1973, is situated in the southern offshoot of the Satpura mountain range $\left(20^{0} 51^{\prime}-21^{0} 46^{\prime} \mathrm{N} \& 76^{0} 38^{\prime}-77^{0} 33^{\prime} \mathrm{E}\right)$. The total tiger reserve area of about $1676.93 \mathrm{~km}^{2}$ including critical tiger habitat area of $361.28 \mathrm{~km}^{2 *}$ (*Gugamal division) is lies in two districts, Akola and Amravati in Maharashtra (Chandrakar et al. 2007; Narasimmarajan et al. 2011). The Melghat region experiences tropical climate with temperatures ranging between $13^{\circ} \mathrm{C}$ in winter and $45^{\circ} \mathrm{C}$ during summer. The annual rainfall ranges between 1000 and 2250 $\mathrm{mm}$. A total of 715 plant species were recorded in the Melghat Tiger Reserve (Mahabal 2005). The survey was carried out in three ranges of Gugamal division in the Melghat Tiger Reserve, which is Dhargad, Dhakna and Chikaldara with the area surveyed about $250 \mathrm{~km}^{2}$ (Image 1).

Material and Methods: Population densities and group size of the GJ were estimated by the line transect method using Distance Sampling (Burnham et al. 1980; Buckland et al. 1993, 2001). We walked 34 line transects ( $2 \mathrm{~km}$ length), each having five temporal replicates to record the encounter rate of GJ. On every walk, we recorded sightings, group size, sighting angle using a hand held compass (KB 20, Santo, Vantaa, Finland), and sighting distance using laser range finder (Bushnell, Overland Park, Kansas, USA). We laid 170 circular plots in order to describe and evaluate the impact of biotic disturbance and emphasis habitat preference of the GJ. Five circular plots were laid at each transect having a $20 \mathrm{~m}$ radius at a distance of every $400 \mathrm{~m}$. On every plot, data on trees, shrubs, herbs, grass and leaf litter cover, human disturbance, tree lopping, wood/bamboo cutting, people seen and the presence of human trail were recorded (Johnsingh 1987; Sathyakumar 2006). A total of 170 circular plots were laid in order to estimate the impact of biotic 


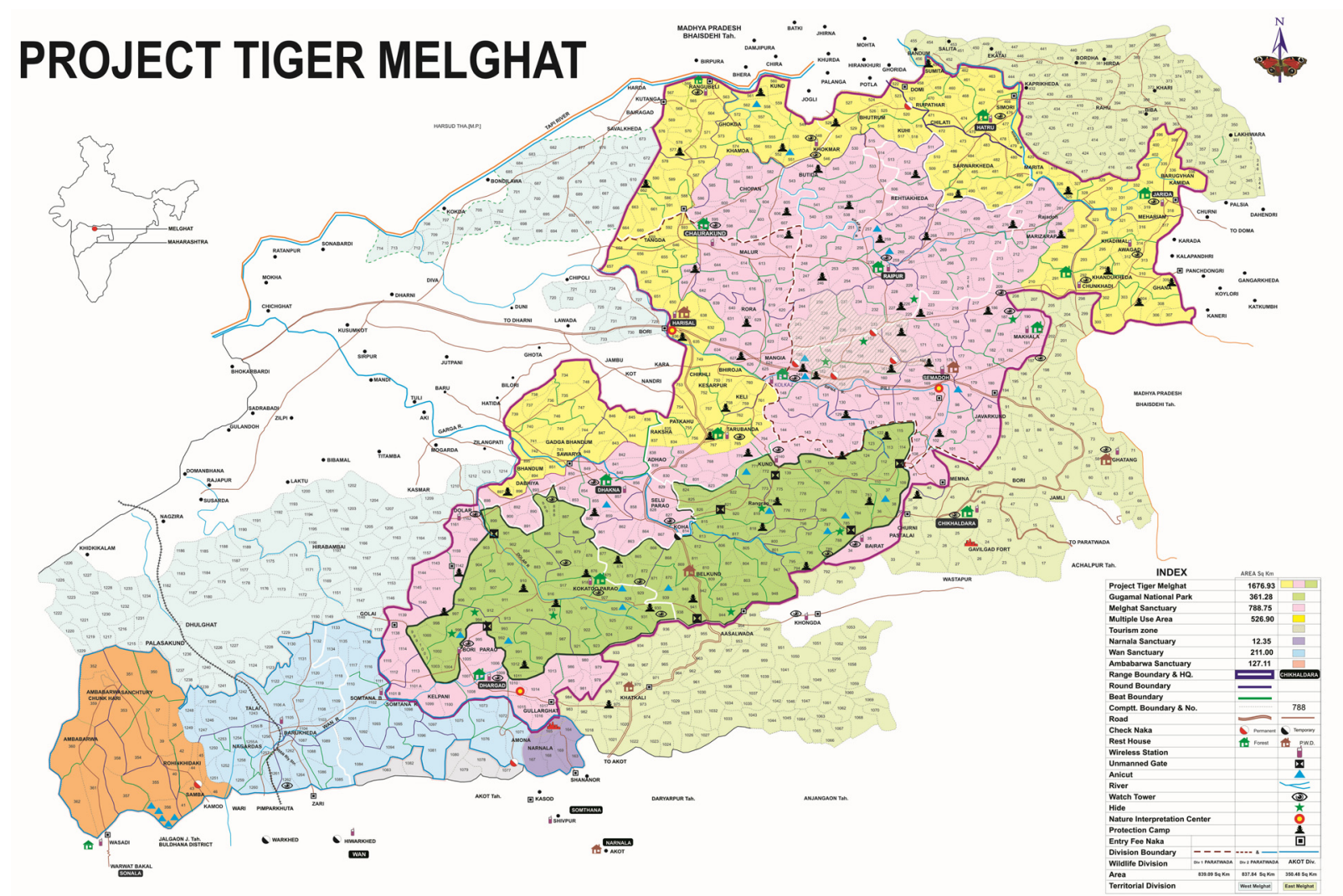

Image 1. The Grey Junglefowl Gallus sonneratii survey site of Melghat Tiger Reserve, Maharashtra

disturbance on the GJ, habitat and habitat preferences were also investigated during the survey period. The disturbances were subjectively categorized into highly disturbed (0.75-1), moderately disturbed $(0.50-0.75)$, less disturbed (0.25-0.50) and least disturbed (0-0.25), respectively. Data of the circular plots $(n=170)$ were pooled to estimate the Mean $( \pm \mathrm{SE})$ of factors associated with biotic disturbances. Pooled line transect data were used to estimated the population density and group size of GJ using program DISTANCE 5.0 (Thomas et al. 2006).

Results and Discussion: Population density: A total of 36 GJ sightings comprising 114 individuals were recorded during (total effort 170 transect walks) the entire study period. An overall density of GJ 16.72 \pm 4.70 Birds $/ \mathrm{km}^{2},(\mathrm{n}=36)$ the average group density was $5.68 \pm 1.49$, $(\mathrm{n}=36)$ whereas the average cluster size was 2.95 birds $(\mathrm{n}=36), \mathrm{P}=0.5157$ (Table 1). Best fit model (Hazard/Hermite) was chosen on the basis of minimum $\mathrm{AIC}=248.55$. The encounter rate of GJ $0.39 \pm 0.2 / \mathrm{km}^{2}$ was also determined from the analysis (Fig. 1). The highest number of GJ recorded in a sighting was five individuals and the least was one individual among all the sightings recorded and mean group size was 3.16 individuals. Studies conducted elsewhere on the GJ have shown different estimates of population density. Subhani et al. (2000) estimated an overall density of $7.87 \mathrm{birds} / \mathrm{km}^{2}$ in Deva Vetala National Park and Das (2006) estimated density of 5.39 birds/ha in Rajaji National Park. The variation in density estimates in different studies could be due to the differences in methodology and habitat in the study areas besides many other factors may influence such as season, annual variations and observer differences.

Habitat preference and biotic disturbance: In the Melghat Tiger Reserve, GJs were generally observed in areas having mixed deciduous forest with Tectona grandis and Dendrocalamus strictus. Other species in this habitat included Terminalia tomentosa, Anogeissus latifolia, Butea monosperma, Emblica offficinalis, Boswellia serrata, Ougeinia oojeinensis, Laegerstromia parviflora, Lantana camara and Ziziphus mauritiana (Champion \& Seth 1968), which probably helped in camouflage for the GJ in the study area (Johnsingh 1987, 1994; Sathyakumar 2006). Estimated biotic disturbance indicators were Mean \pm SE 
Table 1. Population density and average group size of Grey Junglefowl (Gallus sonneratii) in Melghat Tiger Reserve, Maharashtra (October 2010 to March 2011).

\begin{tabular}{|c|c|c|c|c|c|}
\hline Parameter & Point estimate & Standard error & $\begin{array}{c}\text { Percent coeficient } \\
\text { of variation }\end{array}$ & $\begin{array}{c}95 \% \text { percent } \\
\text { confidence interval }\end{array}$ \\
\hline DS & 5.6825 & 1.4915 & 26.25 & 3.3834 & 9.5437 \\
\hline E(S) & 2.9439 & 0.2959 & 10.05 & 2.4011 & 9.6423 \\
\hline D & 16.728 & 4.7018 & 28.11 & 29.094 & 10.000 \\
\hline N & 17.000 & 4.7781 & 28.11 & 29.000 \\
\hline
\end{tabular}

DS - estimate average group size; $E(S)$ - estimate expected value of cluster size; D - estimate of density of animals; $N$ - estimate no. of animals in the specified area. Chi-square value $\mathrm{P}=0.5157$

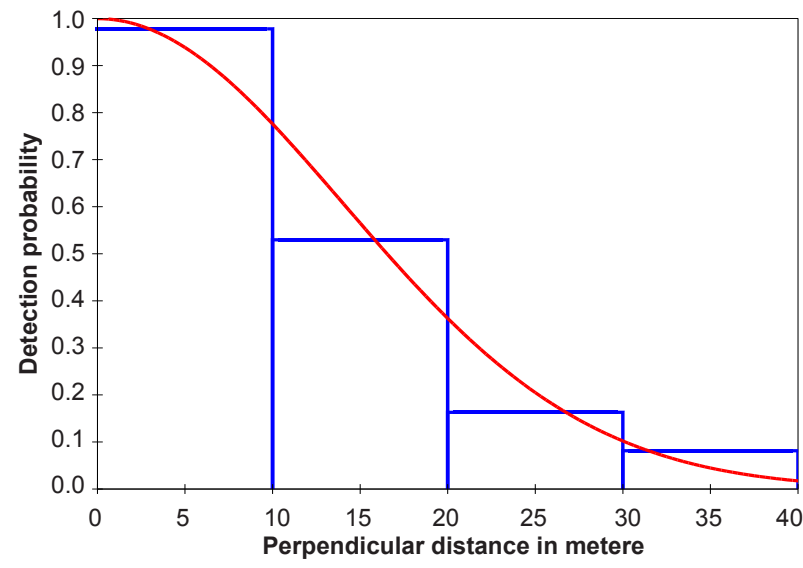

Figure 1. Results of model fitted in the DISTANCE to estimate detection probability and effective strip width of Grey Junglefowl sightings in dry and mixed deciduous habitats of Melghat Tiger Reserve.

of tree cutting $0.25 \pm 0.07$, presence of human trails $0.16 \pm 0.02$, number of trees lopped $0.05 \pm 0.08$, grass/ bamboo cutting $0.02 \pm 0.01$ and people seen $0.01 \pm 0.02$ recorded from the study area (Fig. 2).

Johnsgard (1986) reported that the GJ inhabits a wide variety of habitats, from secondary dry deciduous to moist evergreen forests, but is especially common in bamboo thickets, edges of village forests around cultivated fields and around clearings or neglected plantations. In the Periyar Tiger Reserve, GJ have been sighted frequently near human inhabitations but they were absent in the high hills (Zacharias 1997). The species showed a preference for areas with a mix of slopes, hilly, plains as well as the less forested areas and open grassland patches (Subramanian et al. 2008). Consequently the Melghat Tiger reserve, GJs were encountered mostly in areas having dense mixed deciduous forests where the biotic disturbances were in low intensity. They avoided human habitations and high hills with open areas.

Habitat preference is a dynamic process in the

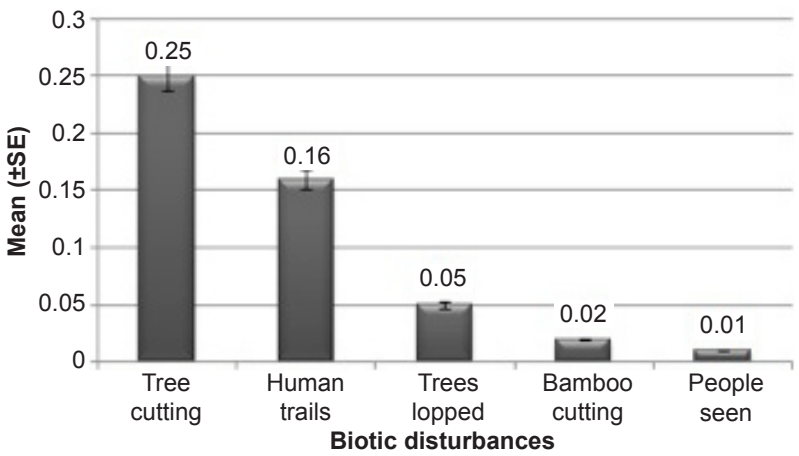

Figure 2. Estimated Mean ( $\pm S E$ ) of biotic disturbances recorded from Melghat Tiger Reserve, Maharashtra during (October 2010 to March 2011).

natural systems. Many species are confined to specific habitat types (Winkler \& Leisler 1985). Based on our observations, we suggest that human disturbance, cattle grazing and tree/grass cutting activities were probably the major threats to the species in this area. This has probably pushed the GJ back in to the dense shrubby areas of the Tiger reserve. Further study is needed to understand the ecology and conservation threats of the species in Melghat Tiger Reserve.

\section{REFERENCES}

BirdLife International (2012). Gallus sonneratii. In: IUCN 2012. IUCN Red List of Threatened Species. Version 2012.1. <www.iucnredlist.org>. Downloaded on 21 July 2012.

Buckland, S.T., D.R. Anderson K.P. Burnham \& J.L. Laake (1993). Distance Sampling: Estimating Abundance of Biological Populations. Chapman and Hall, London, $361 \mathrm{pp}$.

Buckland, S.T., D.R. Anderson K.P. Burnham J.L. Laake D.L. Borchers \& L. Thomas (2001). Introduction to Distance Sampling. Oxford University Press, London, $361 \mathrm{pp}$

Burnham, K.P., D.R. Anderson \& J.L. Laake (1980). 
Estimation of density from line transects sampling of biological populations. Wildlife Monogram 72: 1-202

Chandrakar, M., S. Palekar \& S. Chandrakar (2007). Butterfly fauna of Melghat region, Maharashtra. Zoos' Print Journal 22(7): 2762-2764.

Champion, H.G. \& S.K. Seth (1968). A revised survey of the forest types of India. Government of India Press, New Delhi, 17pp.

Das, N. (2006). Distribution, status and habitat preference of the Red Jungle Fowl in the Rajaji National Park. Unpublished M.Sc. Forestry (Economics \& Management) Thesis. Forest Research Institute, Dehradun, India.

Furness, R.W. \& J.J.D. Greenwood (1993). Birds As A Monitor of Environmental Change. Chapman and Hall, London, 34pp

Galliformes of India (2007). Envis Bulletin Wildlife and Protected Area, Vol. 10 No.1. Wildlife institute of India, Dehradun, 274pp

Gill, F.B. (1994). Ornithology-2nd Edition. Oxford University Press, New York, 117pp

Johnsgard, P.A. (1986). The Pheasants of The World. Oxford University Press, 113-128pp.

Johnsingh, A.J.T. \& J. Joshua (1994). Avifauna in three vegetation types on Mundanthurai plateau, south India. Journal of Tropical Ecology 10: 323-335.

Johnsingh, A.J.T., N.H. Martin, J. Balasingh \& V. Chelladurai (1987). Vegetation and avifauna in a thorn scrub habitat in South India. Journal of Tropical Ecology 28: $22-34$.

Mahabal, A. (2005). An Overview - Fauna of Melghat Tiger Reserve. Conservation Area Series, 24. Zoological Survey of India, Kolkata, 1-10pp.

Narasimmarajan, K., B.B. Barman \& L. Puia (2011). A new record of Caracal (Caracal caracal) in Melghat Tiger
Reserve Maharashtra, Central India - after decades. Journal of Research in Biology 6: 399-402.

Ramakrishnan, P. (1983). Environmental studies on the birds of Malabar Forest. PhD Thesis. University of Calicut.

Sathyakumar, S. (2006). Habitat use by Grey Junglefowl at Mundanthurai plateau, Tamil Nadu. Journal of the Bombay Natural History Society 103(1): 57-61.

Schwartz, C.W. \& E.R. Schwartz (1951). An ecological reconnaissance of the pheasants of Hawaii. Auk 68: 281314.

Subramanian, C., C.R. Kumar \& M.C. Sathyanarayana (2008). Microhabitat use by Grey Junglefowl (Gallus sonneratii) at Theni forest division, South India. Applied Ecology and Environmental Research 6(4): 61-68.

Subhani, A., S.A. Muhammad, M. Anwar, U. Ali \& I.D. Naeem (2000). Population Status and Distribution Pattern of Red Jungle Fowl (Gallus gallus murghi) in Deva Vatala National Park, Azad Jammu \& Kashmir, Pakistan: A Pioneer Study. Pakistan Journal of Zoology 42(6): 701-706.

Thomas, L., J.L. Laake, E. Rexstad, S. Strindberg, F.F.C. Marques, S.T. Buckland, D.L. Borchers, D.R. Anderson, K.P. Burnham, M.L. Burt, S.L. Hedley, J.H. Pollard, J.R.B. Bishop \& T.A. Marques (2009). Distance 5.0. Research Unit for Wildlife Population Assessment. University of St. Andrews, UK. http://www.ruwpa.st-and. ac.uk/distance.

Winkler, H. \& B. Leisler (1985). Morphological aspects of habitat selection in birds, pp. 415-435. In: Cody, M.L. (ed.). Habitat Selection in Birds. Academic Press Inc., New York.

Zacharias, V.J. (1997). Status of Grey Junglefowl (Gallus sonneratti) in Periyar Tiger Reserve. Tragopan Issue 7: $13-15$. 